\title{
Pengembangan Permainan Element Go Sebagai Media Pembelajaran Pada Materi Konfigurasi Elektron Yang Mempengaruhi Retensi Peserta Didik

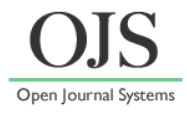

\author{
Mayang Tri Wijayanti ${ }^{*}$, Achmad Lutfi \\ Program Studi Pendidikan Kimia, Universitas Negeri Surabaya \\ *Email: mayang.17030194014@mhs.unesa.ac.id
}

DOI: https://doi.org/10.33369/pendipa.5.3.269-276

\begin{abstract}
The aims of this study was to obtain chemistry learning media, namely android-based educational games that affect students' retention of electron configuration material. The research method used is research and development (Research and Development/ $R \& D$ ). The data collection instruments in this study were validation sheets, student activity observation sheets, student response questionnaire sheets, and test question sheets. The subjects in this study were 34 students of class X SMA Negeri Surabaya. The validation results show that the percentage of validity obtained is $84.5 \%$ with the very good category. The test results show that the game Element Go is a practical game because it has received a positive response from students and three observers of student activity, which the percentage of responses from all its aspects is $\geq 61 \%$. The effectiveness of the game developed as a learning medium can be seen from the classical completeness posttest which reflects the learning outcomes of students by $100 \%$ with a very good category. The retention ability analysis showed a result of $93.07 \%$ (very good category) meaning that learning using game media had a high influence on the retention ability of students.
\end{abstract}

Keywords: Game; electron configuration; retention.

\begin{abstract}
ABSTRAK
Penelitian ini bertujuan untuk memperoleh media pembelajaran kimia yaitu permainan edukatif berbasis android yang mempengaruhi retensi peserta didik terhadap materi konfigurasi elektron. Metode penelitian yang digunakan adalah penelitian dan pengembangan (Research and Development/ R\&D). Instrumen pengumpulan data dalam penelitian ini adalah lembar validasi, lembar observasi aktivitas peserta didik, lembar angket respon peserta didik, dan lembar soal tes. Subjek pada penelitian ini adalah 34 peserta didik kelas X SMA Negeri Surabaya. Hasil validasi menunjukkan bahwa persentase validitas yang diperoleh sebesar $84,5 \%$ dengan kategori sangat baik. Hasil uji coba menunjukkan bahwa permainan Element Go merupakan suatu permainan yang praktis karena diperoleh respon positif dari peserta didik dan tiga orang pengamat aktivitas peserta didik, yang persentase respon dari seluruh aspeknya $\geq 61 \%$. Keefektifan permainan yang dikembangkan sebagai media pembelajaran terlihat dari ketuntasan klasikal posttest yang mencerminkan hasil belajar peserta didik sebesar $100 \%$ dengan kategori sangat baik. Analisis kemampuan retensi menunjukkan hasil sebesar 93,07\% (kategori sangat baik) artinya pembelajaran dengan menggunakan media permainan memberi pengaruh tinggi terhadap kemampuan retensi peserta didik.
\end{abstract}

Kata kunci: Permainan; konfigurasi elektron; retensi.

\section{PENDAHULUAN}

Keberhasilan belajar kimia umumnya diukur dari kemampuan peserta didik untuk menguasai konsep yang telah dipelajari. Namun menurut Handayani dan Agustini (2016) keberhasilan belajar diukur berdasarkan penguasaaan konsep yang bertahan lama dalam pemahaman peserta didik sehingga ke depannya konsep tersebut dapat dimanfaatkan pada pembelajaran selanjutnya. Salah satu konsep kimia yang perlu dipelajari peserta didik adalah konfigurasi elektron yang dianggap bersifat abstrak karena fenomena dalam konsep ini tidak bisa diamati 
secara langsung melainkan perlu diberikan sebuah visualisasi yang dapat memudahkan peserta didik untuk memahaminya. Sejalan dengan Magdalena (2017), yang menyatakan bahwa perlu cara tertentu untuk membantu mempermudah pemahaman konsep struktur atom yang bersifat abstrak misalkan saja pada saat menentukan konfigurasi elektron dari suatu unsur.

Proses pembelajaran yang dilaksanakan oleh guru akan mempengaruhi retensi belajar peserta didik. Retensi merupakan kemampuan untuk menyimpan dan menghadirkan kembali informasi yang telah diperoleh pada saat dibutuhkan dalam bentuk verbal atau dalam bentuk visual (Nofindra, 2019). Akan tetapi daya ingat terhadap suatu informasi akan berkurang sesuai interval waktu tertentu, yang biasa dikatakan sebagai lupa. Lupa merupakan permasalahan universal yang dapat terjadi kepada siapapun. Peserta didik dapat lupa terhadap materi pelajaran, bahkan materi yang baru saja ia pelajari. Keterbatasan daya ingat yang dimiliki peserta didik membuat guru harus sering melakukan pengulangan informasi terkait materi yang telah disampaikan atau dengan memaksimalkan waktu pembelajaran di kelas dan juga pemberian tugas rumah untuk membaca atau meringkas materi pelajaran.

Berdasarkan observasi peneliti didapatkan informasi bahwa sekitar $65 \%$ peserta didik belum paham terhadap materi konfigurasi elektron sebab selama proses pembelajaran terutama pada masa pandemi seperti ini guru hanya diberikan waktu mengajar secara daring yang singkat sehingga guru hanya mengajarkan konsep dengan cara memindahkan informasi dan memberikan contoh yang cenderung dihafalkan oleh peserta didik. Hal tersebut mengakibatkan peserta didik mudah lupa dengan konsep yang telah dipelajarinya sehingga mempengaruhi hasil belajar mereka. Hal ini diperkuat dengan hasil wawancara bersama guru kimia di SMA Negeri Surabaya pada tanggal 12 November 2020, dimana karena keterbatasan waktu mengajar menggunakan aplikasi OFFICE 365 maka proses mengajar hanya dilakukan dengan metode ceramah dan juga powerpoint untuk mendukung kegiatan belajar mengajar sehingga didapatkan hasil belajar yang kurang maksimal.
Berdasarkan Depdikbud (2016) prinsip yang digunakan dalam pembelajaran salah satunya adalah dengan pemanfaatan teknologi informasi dan komunikasi untuk meningkatkan efisiensi dan efektivitas pembelajaran. Pembelajaran dikatakan efektif jika tujuan pembelajaran dan kriteria ketuntasan belajar telah tercapai dan pembelajaran dikatakan efisien apabila terdapat kesinambungan antara waktu yang digunakan dengan hasil belajar yang diperoleh. Saat ini penggunaan perangkat mobile seperti smartphone sudah menjadi kebutuhan di seluruh kalangan termasuk kalangan pelajar. Smartphone yang berbasis android berkembang dengan pesat dan menjadi tren masa kini, sehingga pengembangan media pembelajaran dengan menggunakan sistem android ini cukup menjanjikan. Menurut Utami dkk. (2016) perangkat android selain digunakan untuk berkomunikasi, juga bisa dimanfaatkan sebagai media pembelajaran interaktif untuk peserta didik.

Oleh karena itu dibutuhkan inovasi penyajian soal-soal kimia yang menarik minat belajar kimia misalkan saja dengan menggunakan permainan sebagai media pembelajaran. Tampilan warna, gambar, atau video yang terdapat dalam permainan dapat mempermudah pemahaman dan memperkuat retensi peserta didik terhadap suatu materi sehingga pembelajaran menjadi lebih bermakna. Kegiatan belajar yang menyenangkan menggunakan permainan dapat mencegah kebosanan, tinggalkan kesan panjang di memori siswa, dan menciptakan suasana yang lebih menyenangkan selama proses belajar mengajar tanpa meninggalkan tujuan pembelajaran (Qomariyah, 2016).

Permainan Element Go berbasis android yang dikembangkan memuat materi dan soal latihan tentang konfigurasi elektron. Permainan ini membutuhkan konsentrasi dan strategi tersendiri untuk menyelesaikannya. Permainan Element Go merupakan permainan edukatif yang menghadirkan kesan baru dalam proses belajar mengajar dan tetap memberikan rasa kenyamanan dalam belajar sehingga peserta didik dapat mencapai ketuntasan hasil belajar dan retensinya pun juga meningkat. Permainan seperti ini belum tersedia, maka dari itu tujuan penelitian ini adalah mengembangkan permainan 
sebagai inovasi media pembelajaran kimia yang layak dan juga memberikan pengaruh yang tinggi terhadap retensi peserta didik pada materi konfigurasi elektron.

\section{METODE PENELITIAN}

Penelitian ini menggunakan metode penelitian dan pengembangan (Research and Development/ R\&D). Metode penelitian $\mathrm{R} \& \mathrm{D}$ merupakan metode penelitian yang dipakai untuk menghasilkan suatu produk dan menguji keefektifan produk tersebut (Peprizal dan Syah, 2020). Langkah-langkah dalam metode ini yaitu potensi dan masalah, mengumpulkan informasi, desain produk, validasi desain, perbaikan desain, uji coba produk, uji coba penggunaan, perbaikan produk, dan pembuatan produk secara masal. Penelitian ini hanya sampai pada langkah uji coba produk karena hanya digunakan pada uji coba kelayakan. Penelitian ini dilaksanakan di SMA Negeri Kota Surabaya dengan subjek penelitian yaitu 34 peserta didik kelas $\mathrm{X}$ pada semester ganjil tahun ajaran 2020/2021 selama tiga kali pertemuan. Setiap pertemuan dalam pelaksanaannya membutuhkan waktu sekitar 45 menit.

Instrumen yang digunakan dalam penelitian ini adalah lembar validasi, lembar angket respon peserta didik, lembar observasi aktivitas peserta didik, dan lembar soal tes. Teknik pengumpulan data dilakukan dengan tiga cara yaitu 1) pemberian angket validasi kepada 3 validator melalui Skala Likert dimana terdapat pernyataan positif dan negatif yang dinilai dengan lima indikator; tidak baik, kurang baik, cukup, baik, dan sangat baik, 2) pemberian soal tes terkait materi konfigurasi elektron yang terdiri atas 25 soal pilihan ganda, dan 3) pemberian angket respon kepada peserta didik dan tiga orang pengamat aktivitas peserta didik melalui Skala Guttman dimana terdapat pernyataan positif dan juga negatif yang dinilai dengan dua indikator; ya dan tidak. Data yang diperoleh kemudian dianalisis dengan menggunakan empat teknik sebagai berikut:

1. Uji kevalidan dengan menggunakan rumus perhitungan persentase nilai kevalidan

$$
\mathrm{P}(\%)=\frac{\text { sskore hasil pengumpulan data }}{\text { skor kriterium }} \times 100 \%
$$

Berdasarkan presentase kevalidan, permainan Element Go sebagai media pembelajaran, dikatakan valid apabila presentasenya $\geq 61 \%$.

2. Uji kepraktisan dengan menggunakan perhitungan persentase angket respon peserta didik dan angket observasi aktivitas peserta didik berdasarkan kriteria Skala Guttman

$\mathrm{P}=\frac{\text { jumlah jawaban ya }}{\text { jumlah maksimal jawaban ya }} \times 100 \%$

Berdasarkan hasil perhitungan tersebut permainan Element Go dikatakan telah menjadi permainan yang praktis apabila hasil rata-rata persentase yang menjawab "Ya" $\geq 61 \%$.

3. Uji keefektifan dengan menggunakan progam SPSS berupa Uji normalitas dan Uji $\mathrm{t}$ berpasangan dengan taraf kepercayaan 95\%. Ketuntasan hasil belajar dapat diketahui melalui perhitungan ketuntasan klasikal sebagai berikut:

Ketuntasan klasikal $=$ $\frac{\text { Jumlah peserta didik yang tuntas }}{\text { Jumlah keseluruhan peserta didik }} \times 100 \%$

Ketuntasan klasikal dapat dicapai jika persentase siswa yang telah mencapai ketuntasan $\geq 80 \%$ (Lutfi dan Nugroho, 2019).

4. Uji kemampuan retensi dengan menggunakan rumus perhitungan sebagai berikut:

Retensi $=\frac{\text { Hasil } \text { Tes } \text { Tund } a}{\text { Hasil Posttest }} \times 100 \%$

Hasil retensi peserta didik ini kemudian dikategorikan sesuai kriteria retensi menurut Hasanah (2017) dengan tiga tingkat retensi yaitu: 1) $\mathrm{R} \geq 70 \%$ dikategorikan tinggi, 2) $60 \%<\mathrm{R}<70 \%$ dikategorikan sedang, dan 3) $\mathrm{R} \leq 60 \%$ dikategorikan rendah.

\section{HASIL DAN PEMBAHASAN}

Pengembangan permainan Element Go diawali dengan studi pendahuluan di SMA Negeri Surabaya. Berdasarkan hasil studi pendahuluan diketahui jika pelajaran kimia dianggap sulit khususnya untuk peserta didik kelas X karena sebelumnya di bangku SMP mereka belum pernah menerima pelajaran kimia melainkan hanya mendapatkan pelajaran IPA 
saja itu pun kurang mendalam. Proses pembelajaran daring seperti saat ini dilakukan dengan menggunakan berbagai aplikasi penunjang pembelajaran seperti Google Meet, Zoom, Microsoft Teams, dan lain-lain. Media pembelajaran yang digunakan selama ini adalah PPT, ukbm, dan buku paket. Namun karena adanya keterbatasan waktu untuk setiap kali pertemuan maka proses pembelajaran cenderung diarahkan untuk mengerjakan soal yang ada di ukbm atau buku paket kemudian perwakilan peserta didik menunjukkan hasil pengerjaan soal lalu dibahas bersama-sama. Seiring berjalannya waktu, timbul rasa bosan terhadap proses pembelajaran secara daring. Oleh karena itu untuk menunjang kegiatan pembelajaran guna mencapai ketuntasan hasil belajar diperlukan sebuah inovasi media pembelajaran yang menarik dan memudahkan proses pemahaman materi, misalnya dengan menggunakan permainan sehingga mereka dapat belajar sekaligus bermain. Tahap selanjutnya adalah pembuatan desain produk atau storyboard yang nantinya akan dikembangkan oleh programmer game sehingga akhirnya dihasilkan produk permainan. Selanjutnya dilakukan proses telaah permainan oleh dosen pembimbing untuk mengetahui kekurangan-kekurangan dalam permainan kemudian dilakukan perbaikan permainan.

\section{Uji validasi}

Setelah itu dilakukan tahap validasi untuk mengetahui kevalidan permainan Element Go yang dikembangkan sebagai media pembelajaran. Validasi permainan diperoleh dari sejumlah pernyataan terkait persyaratan isi dan persyaratan konstruk permainan dalam lembar angket validasi permainan. Adapun data hasil validasi disajikan dalam Tabel 1.

Tabel 1. Hasil data validasi

\begin{tabular}{lllllll}
\hline $\mathbf{N}$ & Indikator & \multicolumn{2}{c}{$\begin{array}{c}\text { Hasil } \\
\text { persentase } \\
(\mathbf{1 0 0 \% )}\end{array}$} & $\begin{array}{l}\text { \% } \\
\text { rata- } \\
\text { rata }\end{array}$ & $\begin{array}{l}\text { Kat } \\
\text { e- } \\
\text { gori }\end{array}$ \\
\cline { 2 - 4 } & V1 & $\mathbf{V 2}$ & $\mathbf{V 3}$ & & \\
\hline 1. & $\begin{array}{l}\text { Validitas } \\
\text { isi }\end{array}$ & 80 & 70 & 90 & 80 & $\begin{array}{l}\text { vali } \\
\text { d }\end{array}$ \\
\hline $\begin{array}{l}\text { 2. } \\
\text { Validitas } \\
\text { konstruk }\end{array}$ & 93 & 80 & 95 & 89 & $\begin{array}{l}\text { vali } \\
\text { d }\end{array}$ \\
\hline
\end{tabular}

Tabel 1 menunjukkan bahwa persentase kelayakan ditinjau dari aspek validitas isi dan validitas konstruk memperoleh hasil rata-rata sebesar $80 \%$ dan $89 \%$. Adapun rata-rata persentase dari keseluruhan aspek kevalidan adalah sebesar $84,5 \%$, yang artinya permainan Element Go sangat layak digunakan sebagai media pembelajaran pada materi konfigurasi elektron.

\section{Uji kepraktisan}

Keberhasilan penerapan permainan Element Go sebagai media pembelajaran bukan hanya dilihat dari semakin meningkatnya hasil belajar peserta didik, tetapi juga ditunjukkan berdasarkan respon positif dari peserta didik dan juga pengamat. Secara lebih jelas hasil data respon ditunjukkan pada Tabel 2.

Tabel 2. Hasil data respon peserta didik

\begin{tabular}{|c|c|c|c|}
\hline $\begin{array}{l}\mathbf{N} \\
\text { o. }\end{array}$ & Aspek & $\begin{array}{l}\text { Pers } \\
\text { entas } \\
\text { e }(\%)\end{array}$ & $\begin{array}{l}\text { Kateg } \\
\text { ori }\end{array}$ \\
\hline 1. & $\begin{array}{lr}\text { Ketertarikan } & \text { terhadap } \\
\text { permaianan } & \text { Element } \\
\text { Go sebagai media } \\
\text { pembelajaran }\end{array}$ & $\begin{array}{l}87,2 \\
5\end{array}$ & Setuju \\
\hline 2. & $\begin{array}{l}\text { Keterbaruan } \\
\text { permainan Element Go }\end{array}$ & 86 & Setuju \\
\hline 3. & $\begin{array}{l}\text { Kebermanfaatan } \\
\text { permainan Element Go }\end{array}$ & 87 & Setuju \\
\hline 4. & $\begin{array}{l}\text { Kemudahan dalam } \\
\text { mengoperasikan } \\
\text { permainan Element Go }\end{array}$ & 82,5 & Setuju \\
\hline
\end{tabular}

Tabel 2 menunjukkan bahwa persentase kepraktisan ditinjau dari aspek ketertarikan terhadap media permainan, aspek keterbaruan permainan, aspek kebermanfaatan permainan, dan aspek kemudahan dalam mengoperasikan permainan secara berturut-turut memperoleh nilai rata-rata sebesar $87,25 \%, 86 \%, 87 \%$, dan $82,5 \%$, sehingga dapat disimpulkan bahwa permainan Element Go sangat praktis dijadikan sebagai media pembelajaran pada materi konfigurasi elektron. Selain respon dari peserta didik, untuk menentukan kepraktisan permainan Element Go maka dapat juga digunakan data hasil observasi aktivitas peserta didik yang dinilai oleh tiga orang pengamat. Secara lebih 
jelas hasil data observasi ditunjukkan pada Tabel 3.

Tabel 3. Hasil observasi aktivitas peserta didik

\begin{tabular}{|c|c|c|c|}
\hline $\begin{array}{l}\text { N } \\
\text { o. }\end{array}$ & Pertanyaan & $\begin{array}{l}\text { Persent } \\
\text { ase }(\%)\end{array}$ & $\begin{array}{l}\text { Kateg } \\
\text { ori }\end{array}$ \\
\hline 1. & $\begin{array}{l}\text { Peserta didik dapat } \\
\text { mengoperasikan } \\
\text { permainan Element Go } \\
\text { sesuai petunjuk } \\
\text { permainan }\end{array}$ & 100 & Setuju \\
\hline 2. & $\begin{array}{l}\text { Peserta didik terpusat } \\
\text { perhatiannya pada } \\
\text { permainan Element Go }\end{array}$ & 100 & Setuju \\
\hline 3. & $\begin{array}{l}\text { Peserta didik membaca } \\
\text { seluruh materi } \\
\text { pembelajaran yang ada } \\
\text { dalam permainan }\end{array}$ & 66,67 & Setuju \\
\hline 4 & $\begin{array}{l}\text { Peserta didik menjawab } \\
\text { pertanyaan yang terdapat } \\
\text { dalam permainan tanpa } \\
\text { melihat jawaban } \\
\text { temannya }\end{array}$ & 66,67 & Setuju \\
\hline 5 & $\begin{array}{l}\text { Peserta didik aktif pada } \\
\text { saat proses pembelajaran } \\
\text { berlangsung }\end{array}$ & 100 & Setuju \\
\hline
\end{tabular}

Tabel 3 menunjukkan bahwa persentase kepraktisan ditinjau dari aspek kemudahan mengoperasikan media permainan, aspek menarik perhatian, aspek membaca keseluruhan materi, aspek kejujuran, dan aspek keaktivan berturut-turut memperoleh rata-rata persentase sebesar 100\%, 100\%, 66,67\%, 66,67\%, dan $100 \%$. Berdasarkan hasil tersebut, maka dapat disimpulkan bahwa permainan Element Go sangat praktis dijadikan sebagai media pembelajaran pada materi konfigurasi elektron.

Tabel 4. Data hasil pretest dan posttest

\begin{tabular}{llllc}
\hline $\begin{array}{l}\text { Kondis } \\
\text { i }\end{array}$ & $\begin{array}{l}\text { Skor } \\
\text { Rata- } \\
\text { rata }\end{array}$ & $\begin{array}{l}\text { Skor } \\
\text { Teren } \\
\text { dah }\end{array}$ & $\begin{array}{l}\text { Skor } \\
\text { Tertinggi }\end{array}$ & $\begin{array}{l}\text { Jumlah } \\
\text { Peserta } \\
\text { Didik }\end{array}$ \\
\hline Pretest & 39,29 & 16 & 56 & 34 \\
Postest & 86,59 & 76 & 100 & 34 \\
\hline
\end{tabular}

\section{Uji keefektifan}

Keefektifan permainan Element Go yang dikembangkan dilihat berdasarkan hasil belajar peserta didik setelah melakukan pretest dan posttest. Adapun data nilai pretest dan posttest yang diperoleh yang ditunjukkan pada tabel 4 . Sebelum dilakukan uji t berpasangan dengan menggunakan SPSS maka terlebih dahulu dilakukan uji normalitas sample kolmogrovsmirnov test. Hasil uji normalitas disajikan pada Tabel 5.

Tabel 5. Hasil Uji Normalitas Sample Kolmogrov-Smirnov Test

\begin{tabular}{|c|c|c|}
\hline Statistic & $\begin{array}{l}\text { Asymp. Sig. (2- } \\
\text { tailed) }\end{array}$ & $\begin{array}{l}\text { Test } \\
\text { Distribution }\end{array}$ \\
\hline ,116 & $200^{\mathrm{c}, \mathrm{d}}$ & Normal \\
\hline
\end{tabular}

Tabel 5 menunjukkan nilai Asymp. Sig. (2-tailed) sebesar 0,200>0,05, artinya data yang dihasilkan berdistribusi normal. Kemudian setelah itu dilakukan uji t berpasangan guna mengetahui perbedaan rata-rata skor pretest dan skor posttest. Adapun kriteria pengujian dalam uji t berpasangan, apabila nilai signifikansi lebih besar dari 0,05 maka $\mathrm{H}_{0}$ diterima dan $\mathrm{H}_{\mathrm{a}}$ ditolak sedangkan jika nilai signifikansi kurang dari 0,05 maka $\mathrm{H}_{0}$ ditolak dan $\mathrm{H}_{\mathrm{a}}$ diterima (Rini dkk., 2021). Hasil data uji t berpasangan disajikan pada Tabel 6 .

Tabel 6. Hasil uji paired sample $t$ test

\begin{tabular}{|c|c|c|c|c|}
\hline & & $\mathbf{t}$ & df & Sig. (2-tailed) \\
\hline Pair & Pre Test - & - & 3 &, 000 \\
\hline 1 & Post Test & 30,291 & & \\
\hline
\end{tabular}

Berdasarkan Tabel 6 diketahui nilai Sig. (2-tailed) sebesar 0,000 $<0,05$, artinya data berada pada daerah penolakan $\mathrm{H}_{0}$. Selain itu untuk menguji hipotesis dalam uji paired sample $t$ test ini dapat dilakukan dengan membandingkan nilai $t_{\text {hitung }}$ dengan $t_{\text {tabel }}$. Nilai $t_{\text {hitung }}(30,291)$ lebih besar daripada nilai $t_{\text {tabel }}$ (2,03452), sehingga $\mathrm{H}_{0}$ ditolak dan $\mathrm{H}_{\mathrm{a}}$ diterima. Artinya terdapat perbedaan signifikan antara skor rata-rata pretest dan skor rata-rata posttest yang menunjukkan adanya pengaruh penggunaan permainan Element Go pada materi konfigurasi elektron dalam meningkatkan retensi peserta didik.

Peserta didik dinyatakan tuntas jika skor mereka sudah mencapai Kriteria Ketuntasan Minimal (KKM), yaitu 75. Setelah dilakukan pretest diketahui jika seluruh peserta didik tidak tuntas karena skor pretest-nya berada di bawah 
75. Kemudian setelah proses pembelajaran dengan menggunakan permainan sebagai media pembelajaran maka selanjutnya dilakukan posttest. Setelah dilakukan posttest didapatkan hasil bahwa seluruh peserta didik memiliki skor di atas 75 , artinya skor posttest telah memenuhi ketuntasan klasikal. Hasil tersebut sesuai dengan pendapat Lutfi dan Nugroho (2019) dimana ketuntasan klasikal dapat dicapai jika persentase siswa yang telah mencapai ketuntasan $\geq 80 \%$. Ketuntasan klasikal skor pretest dan skor posttest disajikan pada Gambar 1.

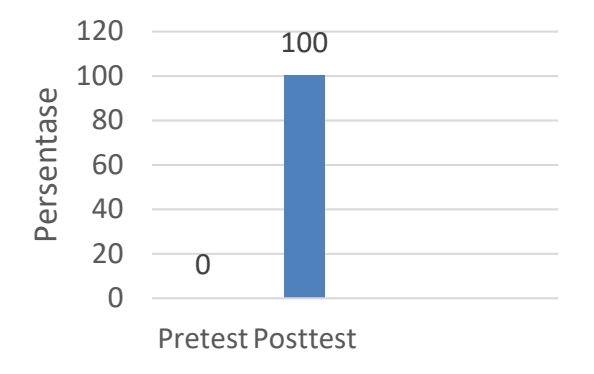

Gambar 1. Ketuntasan klasikal skor pretest dan skor posttest

Berdasarkan Gambar 1 diketahui bahwa terdapat peningkatan ketuntasan klasikal peserta didik dari $0 \%$ menjadi $100 \%$ yang disebabkan karena kemudahan peserta didik dalam memahami materi konfigurasi elektron dengan bantuan permainan Element Go. Menurut Piaget, usia peserta didik SMA telah memasuki tahap operasi formal, di mana apabila dihadapkan pada konsep kimia yang abstrak, mereka dapat menggunakan simbol-simbol yang terkait. Peserta didik diberikan pengalaman belajar secara langung melalui tiga tingkatan level permainan dengan pertanyaan yang berbeda-beda sehingga mereka menjadi lebih aktif mengembangkan pengetahuan yang dimilikinya. Untuk dapat menyelesaikan setiap level dalam permainan maka peserta didik perlu strategi tertentu dalam menjawab seluruh soal yang terdapat dalam berbagai tingkatan level permainan dan juga harus menghindari musuh.

Ketika pemain berhasil menjawab benar soal dalam permainan maka ia akan mendapatkan tambahan skor. Hal itu akan membuat peserta didik menjadi senang dan cenderung mengulanginya yang akan membuat informasi masuk ke memori jangka panjang. Menurut teori pemrosesan informasi, informasi yang diperoleh perlu diatur sedemikian rupa sehingga dapat masuk ke memori jangka panjang. Sesuai hal tersebut, pengaturan informasi dilakukan dengan menggunakan media pembelajaran yaitu berupa permainan Element Go. Hasil belajar peserta didik tercermin dari persentase ketuntasan klasikal posttest yang mendapatkan hasil 100\% tuntas (kategori sangat baik). Hasil tersebut menunjukkan bahwa permainan Element Go efektif dijadikan sebagai media pembelajaran pada materi konfigurasi elektron. Sesuai dengan penelitian Lutfi dkk. (2019) yang memberikan informasi jika hasil belajar siswa telah meningkat setelah menggunakan game sebagai pembelajaran medium dan membuat siswa merasa belajar kimia itu menyenangkan.

\section{Uji retensi}

Media permainan Element Go dapat digunakan untuk meningkatkan kemampuan retensi (daya ingat) peserta didik pada materi konfigurasi elektron. Hasil kemampuan retensi diperoleh berdasarkan perbandingan nilai posttest dan retest yang telah dilakukan. Posttest dilakukan setelah proses pembelajaran dengan menggunakan permainan sebagai media pembelajaran selesai. Kemudian selang waktu satu minggu, dilakukan retest guna melihat retensi peserta didik terhadap materi konfigurasi elektron setelah interval waktu tertentu. Perbandingan persentase nilai posttest dan retest dapat digambarkan dalam gambar 2 .

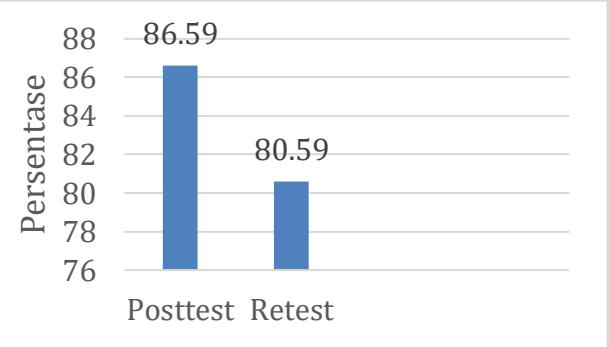

Gambar 2. Pesentase nilai posttest dan retest

Berdasarkan grafik di atas diketahui bahwa persentase nilai posttest adalah $86,59 \%$ sedangkan persentase nilai retest sebesar 80,59. Kemampuan retensi peserta didik pada materi konfigurasi elektron diperoleh melalui perhitungan dengan menggunakan hasil tes tunda (retest) dan hasil posttest. Setelah dilakukan perhitungan maka diperoleh hasil sebesar 
93,07\% artinya retensi peserta didik terhadap materi konfigurasi elektron masih sangat baik meskipun setelah selang waktu 1 minggu proses pembelajaran dengan menggunakan permainan Element Go dan posttest selesai dilakukan. Dalam penelitian ini, permainan sebagai media pembelajaran efektif untuk mempertahankan retensi peserta didik karena menurut Hasanah (2017) hasil retensi peserta didik dalam penelitian ini termasuk ke dalam kategori kriteria retensi yang tinggi $(\mathrm{R} \geq 70 \%)$.

Kemampuan retensi yang diperoleh peserta didik terhadap materi konfigurasi elektron setelah proses pembelajaran dengan menggunakan permainan Element Go bukan hanya bersumber dari pikiran pengajar yang dituangkan ke dalam pikiran peserta didik melainkan berasal dari pengalaman belajar secara langsung melalui aktivitas bermain yang telah dilakukan sehingga peserta didik mampu membangun sendiri konsep-konsep pengetahuan. Hal tersebut sesuai dengan pendapat Silmiati (2017) dimana retensi yang dimiliki peserta didik akan lebih bertahan jika pembelajaran yang dilakukan terasa bermakna bagi mereka.

\section{KESIMPULAN}

Berdasarkan penelitian, maka dapat disimpulkan bahwa permainan Element Go yang dikembangkan dikatakan layak sebagai media pembelajaran pada materi konfigurasi elektron karena telah memenuhi aspek validitas, kepraktisan, dan keefektifan serta dapat memberikan pengaruh yang tinggi terhadap retensi peserta didik pada materi konfigurasi elektron. Adapun rata-rata persentase validitas yang diperoleh sebesar $84,5 \%$ dengan kategori sangat baik sehingga dinyatakan valid. Hasil rata-rata persentase respon peserta didik dan pengamat aktivitas peserta didik pada keseluruhan aspeknya $>61 \%$ sehingga dinyatakan praktis. Hasil belajar peserta didik tercermin dari persentase ketuntasan klasikal posttest yang mendapatkan hasil 100\% tuntas (kategori sangat baik) sehingga dinyatakan efektif. Analisis kemampuan retensi menunjukkan hasil sebesar 93,07\% (kategori sangat baik) artinya pembelajaran dengan menggunakan media permainan memberikan pengaruh tinggi terhadap kemampuan retensi peserta didik.
Berdasarkan hasil penelitian maka dapat diberikan saran, untuk guru diharapkan dapat memanfaatkan permainan yang telah teruji layak sebagai alternatif media pembelajaran kimia di sekolah agar pembelajaran kimia menjadi lebih menarik dan menyenangkan. Bagi peneliti, perlu dilakukan penelitian lanjutan yang berkaitan dengan penggunaan permainan sebagai media pembelajaran kimia yang dapat mempengaruhi hasil belajar dan juga retensi peserta didik.

\section{DAFTAR PUSTAKA}

Depdikbud. (2016). Peraturan Pemerintah Tentang Standar Proses Pendidikan Dasar dan Menengah. Jakarta: Kemendikbud.

Handayani, D., \& Agustini, R. (2016). Pengembangan Permainan Tebak Kata Sebagai Media Pembelajaran Pada Materi Kimia Unsur Kelas XI SMA. Unesa Journal of Chemical Education, 5(2), 503-510.

Hasanah, N. N., Supeno, \& Wahyuni, S. (2017). Kekuatan Retensi Siswa Sma Kelas X Dalam Pembelajaran Fisika Pada Pokok Bahasan Momentum Dan Impuls Menggunakan Lembar Kerja Siswa Berbasis Mind Mapping. Jurnal Pembelajaran dan Pendidikan Sains, 2(1), 25-32.

Lutfi, A., \& Nugroho, A. (2019). Minat Belajar Dan Keberhasilan Belajar Partikel Penyusun Atom Dengan Media Pembelajaran Permainan Chem Man. Jurnal Pembelajaran Kimia, 4(1), 39-50.

Lutfi, A., Suyono, Erman, \& Hidayah, R. (2019). Edutaiment with Computer Game as A Chemistry Learning Media. Jurnal Penelitian Pendidikan Sains, 8(2).

Nofindra, R. (2019). Ingatan, Lupa, Dan Transfer Dalam Belajar Dan Pembelajaran. Jurnal Pendidikan Rokania, 4(1), 21-34.

Peprizal \& Syah, N. (2020). Pengembangan Media Pembelajaran Berbasis Web Pada Mata Pelajaran Instalasi Penerangan Listrik. Jurnal Imiah Pendidikan dan Pembelajaran, 4(3).

Qomariyah, S.S. (2016). Quality of learning media, learning interests, and student learning outcomes: study of economic subjects in class X IIS 12 Public High School Jakarta. Jurnal Pendidikan Ekonomi dan Bisnis, 4(1). 
Rini, E. F. S., Fitriani, R., Matondang, M. M., Yolviansyah, F., Putri, N. D., Agatha, F. L., Lolita, N. (2021). Pengaruh Karakter Kerja Keras terhadap Hasil Belajar Fisika di SMA Negeri 1 Kota Jambi. Journal of Science Education, 5(2), 256-261.

Silmiati, N. Y. (2017). Perbandingan Retensi Siswa SMP Pada Pembelajaran IPA Terpadu Konsep Cahaya Antara Model Pembelajaran Berbasis Masalah Dan Metode Pembelajaran Inkuiri. Jurnal Penelitian Pendidikan, 17(1).
Utami, Fitri, I., Satoto, K. I., \& Martono, K. T. (2016). Teka-teki Unsur Kimia sebagai Media Pembelajaran Kimia Interaktif bagi siswa SMA Kelas X Berbasis Android. Jurnal Teknologi dan Sistem Komputer, 4(1). 